\title{
Spatio-temporal variability of hydro-chemical characteristics of coastal waters of Gulf of Mannar Marine Biosphere Reserve (GoMMBR), South India
}

\author{
K. Kathiravan · Usha Natesan $\cdot$ R. Vishnunath
}

Received: 28 May 2014/ Accepted: 27 October 2014/Published online: 23 November 2014

(C) The Author(s) 2014. This article is published with open access at Springerlink.com

\begin{abstract}
The intention of this study was to appraise the spatial and temporal variations in the physico-chemical parameters of coastal waters of Rameswaram Island, Gulf of Mannar Marine Biosphere Reserve, south India, using multivariate statistical techniques, such as cluster analysis, factor analysis and principal component analysis. Spatiotemporal variations among the physico-chemical parameters are observed in the coastal waters of Gulf of Mannar, especially during northeast and post monsoon seasons. It is inferred that the high loadings of $\mathrm{pH}$, temperature, suspended particulate matter, salinity, dissolved oxygen, biochemical oxygen demand, chlorophyll $a$, nutrient species of nitrogen and phosphorus strongly determine the discrimination of coastal water quality. Results highlight the important role of monsoonal variations to determine the coastal water quality around Rameswaram Island.
\end{abstract}

Keywords Coastal water quality $\cdot$ Rameswaram Island · Physico-chemical variables - Factor analysis (FA) . Principal component analysis (PCA) and cluster analysis (CA)

$\begin{array}{ll}\text { Abbreviations } \\ \text { AS } & \text { Arabian Sea } \\ \text { BoB } & \text { Bay of Bengal } \\ \text { CA } & \text { Cluster analysis } \\ \text { EEZ } & \text { Exclusive economic zone } \\ \text { GoM } & \text { Gulf of Mannar } \\ \text { GPS } & \text { Global positioning system } \\ \text { JMA } & \text { Japan Meteorological Agency }\end{array}$

K. Kathiravan · U. Natesan $(\bowtie) \cdot$ R. Vishnunath

Centre for Water Resources,

Anna University, Chennai 600025, India

e-mail: u_natesan@yahoo.com

$\begin{array}{ll}\text { NIO } & \text { North Indian Ocean } \\ \text { NE } & \text { Northeast monsoon } \\ \text { NMBRP } & \text { National Marine Biosphere Reserve Park } \\ \text { PB } & \text { Palk Bay } \\ \text { PCs } & \text { Principal components } \\ \text { PCA } & \text { Principal component analysis } \\ \text { SMC } & \text { Summer monsoon current } \\ \text { SW } & \text { Southwest monsoon } \\ \text { Sampling stations } \\ \text { PS } & \text { South of Pamban Pass } \\ \text { KI } & \text { Kurusadai Island } \\ \text { KU } & \text { Kunthukal } \\ \text { TK } & \text { Thavukadu } \\ \text { Krk } & \text { South of Kodhandaramar kovil } \\ \text { Mkc } & \text { Mukuntharaiyar Chathiram } \\ \text { Dk } & \text { Dhanushkodi } \\ \text { Dk1 } & \text { 2 km from Dhanushkodi } \\ \text { Dk2 } & 4 \text { km from Dhanushkodi } \\ \text { Dk3 } & 6 \text { km from Dhanushkodi } \\ \text { AmS } & \text { South of Arichamunai } \\ \text { Tip } & \text { Mixing zone between PB and GoM } \\ \text { Tip1 } & \text { Mixing zone of 2 km from Tip }\end{array}$

Introduction

Coastal areas are the most productive as well as valuable habitats. It is subject to great environmental modification because of their dense population, and deterioration in the coastal land use patterns such as urbanization, development of industries and agricultural activities. Monitoring of coastal water quality is one of the main concerns for its degradation and is an informative tool for coastal management and polices. The distribution of nutrients in the 
Fig. 1 Study area with sampling stations

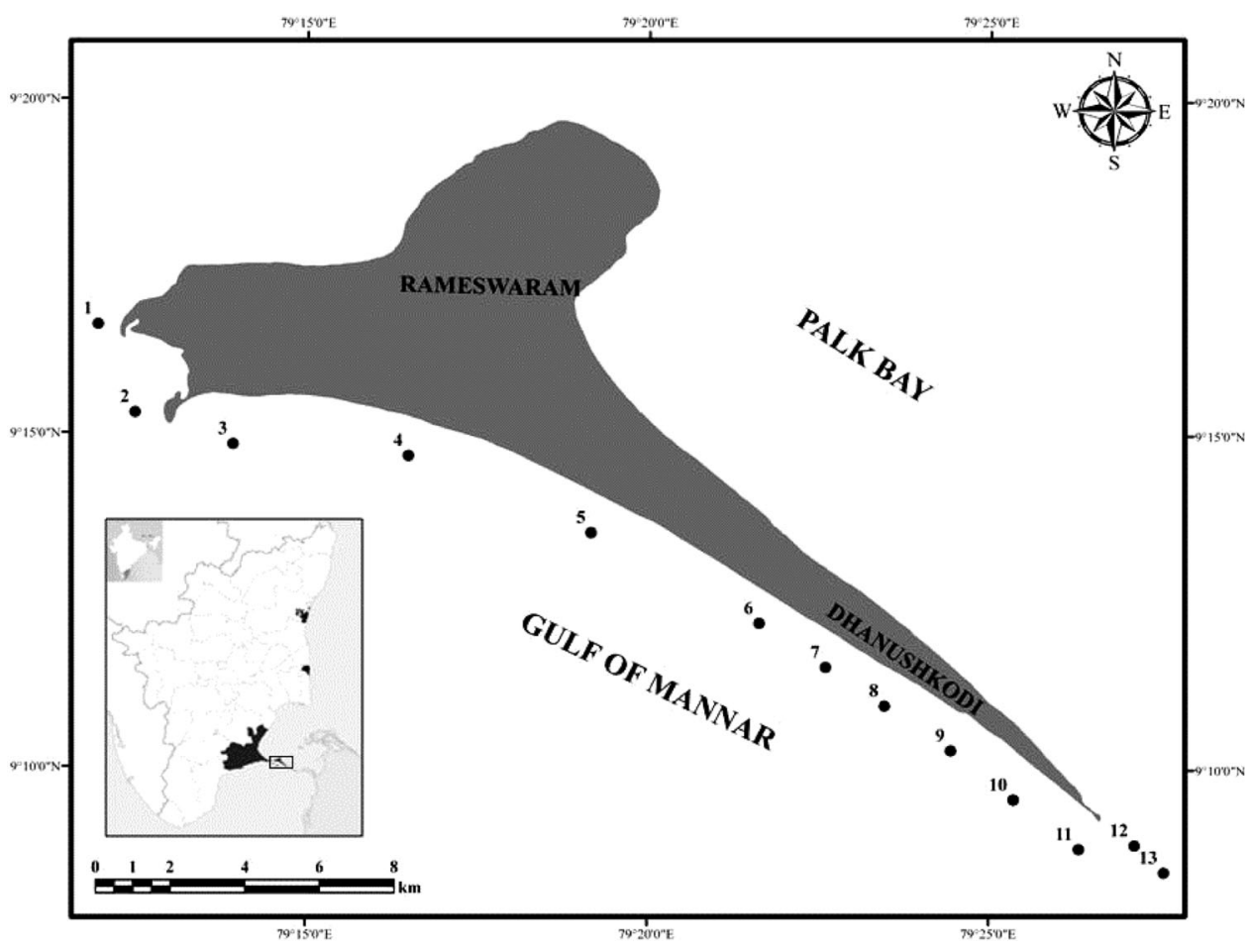

sea water exhibits some variations depending on the local conditions such as rainfall, fresh water inflow, tidal incursion and also biological activities (Sushanth and Rajasekar 2012). Due to the intensification of human activities and urbanization along coastal regions the increase of input of nutrients to the coastal water transpired in the past decades. Coastal areas act as natural filters for suspended sediments and nutrients coming from the land to the open sea. Besides the role of land nutrient discharge, the nutrient concentration variations of coastal marine waters can also be related to oceanic sources, as in the case of areas subject to coastal upwelling events (Matsuura 1986; Gonzalez-Rodriguez et al. 1992; Valentin et al. 1994; Simonassi et al. 2010). During these events, the productivity increases and the temporal variation in the nutrient concentrations in waters can be high (Valentin et al. 1994; Fock 2003; Brandini et al. 2007). Gulf of Mannar (GoM) is located between the northwestern Srilanka and Southeast coast of India and the boundary starts from the southern coast of Rameswaram Island on its north which opens in the south into the North Indian Ocean (NIO). NIO dynamics determines the monsoonal activities particularly in India. GoM intacts with NIO directly as well as receives massive amount of nutrient enriched water from Arabian Sea (AS) as well as freshwater from Bay of Bengal (BoB) during monsoon results in the changes in the coastal water quality, because of the monsoonal currents triumphing in this area. Rameswaram Island is bounded between the longitudes $79^{\circ} 12^{\prime} 30^{\prime \prime} \mathrm{E}$ to $79^{\circ} 21^{\prime} 30^{\prime \prime} \mathrm{E}$ and the latitudes $9^{\circ} 8^{\prime} 55^{\prime \prime} \mathrm{N}$ to $9^{\circ} 19^{\prime} 25^{\prime \prime} \mathrm{N}$ with Palk Bay (PB) on its north and GoM on its south (Fig. 1). The submerged chain of Islands in the Palk Strait and Mannar Island act as physical barriers between GoM and PB (Jyothibabu et al. 2013), which limits the water and sediments exchange. As a result, the hydrography of the GoM is influenced by the AS waters and PB is influenced by the BoB waters (Murty and Varma 1964; Jyothibabu et al. 2013). The climatology of this area has been indulgenced into four seasons in a year, i.e., (1) summer (April-May), (2) southwest (SW) monsoon (June-September), (3) northeast (NE) monsoon (October-December) and (4) post-monsoon (JanuaryMarch). The coastal water quality of Rameswaram Island has not been paid attention when compared to the other research works in GoM and most of the available literature and studies do not indicate the present scenario of the GoM influenced. From this study, the physico-chemical characteristics of the GoM was observed and analyzed with strengthens tools about the seasonal variations.

The multivariate statistical technique is useful in asserting the temporal and spatial variations caused by natural and anthropogenic factors (Shrestha and Kazama 2007; Garizi et al. 2011). Cluster analysis (CA) based on euclidean similarity measure is used to group sites recording similarity in environmental parameters (Arumugam et al. 2013). Principal component analysis (PCA) assists to recognize the factors or origin responsible for seasonal water quality variations (Zare et al. 2011). As the first principal component accounts for the covariation shared by all attributes, this may be a better estimate than simple or weighted averages of the original variables (Babu 
et al. 2010). PCs actually take the cloud of data points and rotate it such a way that maximum variability is visible (Fathy et al. 2012). The most significant variables in the components represented by high loadings (correlation coefficient $>0.7$ ) taken into consideration for evaluating the components (Mazlum et al. 1993). Factor analysis (FA) attempts to explain the correlation between the observations in terms of the underlying factors, which are not directly observable (Yu et al. 2003). In this present study, multivariate statistical techniques such as CA, PCA and FA were applied to the interpretation of complex data matrices to better understand the water quality. It helps in identifying the possible factors/sources that influence water quality (Reghunath et al. 2002; Panda et al. 2006; Bu et al. 2009; Garizi et al. 2011).

\section{Study area}

Rameswaram Island is located in the north boundary of GoM, which is the one of the important islands among the 21 islands of GoM separated from mainland India by the Pamban channel. The Island is located $2 \mathrm{~km}$ from the mainland of Tamil Nadu which comes under a part of the Marine Biosphere Reserve protected by Gulf of Mannar Marine National Park. The island stretching from Pamban in the west to Dhanuskodi in the east separates the Palk Bay and the Gulf of Mannar. Gulf of Mannar joined with Palk Strait via Pamban pass and submerged sand patches between Rameswaram Island and Srilanka. Rameswaram Island is bounded between PB in the northern side and GoM in the southern side (Fig. 1). The length of the island is about $28 \mathrm{~km}$ in the east-west direction. The extreme southeastern part of Rameswaram Island known as Dhanuskodi Foreland is a long sand spit of about $4 \mathrm{~km}$ length formed up to Arichamunai (tip) from Dhanuskodi and it tends to grow longer and wider. The tidal regime is semidiurnal with an average range of $0.3-0.7 \mathrm{~m}$ and hydrodynamics is mainly controlled by the tide currents around the Island. Rameswaram Island comprises a holy pilgrimage site which comes under the sensitive EEZ of Indian coastal water and is surrounded by coral patches and National Marine Biosphere Reserve Park. The most important economic activities are fishing and tourism. During summer, the Island gets inflow of tourists because of the pilgrimage and scenic beauty of the area. During southwest monsoon, the direction of current is clockwise in GoM and the reverse in northeast monsoon.

\section{Materials and methods}

Surface water samples around the Rameswaram Island within $500 \mathrm{~m}$ from the coast were collected monthly at 13
Table 1 Geographical co-ordinates of the sampling stations

\begin{tabular}{|c|c|c|c|c|}
\hline $\begin{array}{l}\text { Stn. } \\
\text { ID }\end{array}$ & Latitude & Longitude & $\begin{array}{l}\text { Depth } \\
(\mathrm{m})\end{array}$ & $\begin{array}{l}\text { Station name and } \\
\text { description }\end{array}$ \\
\hline 1 & $9^{\circ} 16^{\prime} 37.47^{\prime \prime} \mathrm{N}$ & $79^{\circ} 11^{\prime} 56.67^{\prime \prime} \mathrm{E}$ & 6 & $\begin{array}{l}\text { South of Pamban Pass: } \\
\text { fishing, coastal } \\
\text { habitat }\end{array}$ \\
\hline 2 & $9^{\circ} 15^{\prime} 18.43^{\prime \prime} \mathrm{N}$ & $79^{\circ} 12^{\prime} 29.45^{\prime \prime} \mathrm{E}$ & 3 & $\begin{array}{l}\text { Kurusadai Island: } \\
\text { fishing, coral } \\
\text { ecosystem, coastal } \\
\text { habitat }\end{array}$ \\
\hline 3 & $9^{\circ} 14^{\prime} 50.23^{\prime \prime} \mathrm{N}$ & $79^{\circ} 13^{\prime} 55.41^{\prime \prime} \mathrm{E}$ & 3 & $\begin{array}{l}\text { Kunthukal: fishing, } \\
\text { tourism site, coastal } \\
\text { habitat }\end{array}$ \\
\hline 4 & $9^{\circ} 14^{\prime} 40.10^{\prime \prime} \mathrm{N}$ & $79^{\circ} 16^{\prime} 29.48^{\prime \prime} \mathrm{E}$ & 4 & $\begin{array}{l}\text { Thavukadu: fishing, } \\
\text { coastal habitat }\end{array}$ \\
\hline 5 & $9^{\circ} 13^{\prime} 30.84^{\prime \prime} \mathrm{N}$ & $79^{\circ} 19^{\prime} 10.17^{\prime \prime} \mathrm{E}$ & 6 & $\begin{array}{l}\text { South of } \\
\text { Kodhandaramar } \\
\text { kovil: fishing }\end{array}$ \\
\hline 6 & $9^{\circ} 12^{\prime} 10.67^{\prime \prime} \mathrm{N}$ & $79^{\circ} 21^{\prime} 38.03^{\prime \prime} \mathrm{E}$ & 4 & $\begin{array}{l}\text { Mukuntharaiyar } \\
\text { (M.K)Chathiram: } \\
\text { fishing, Tourism site, } \\
\text { Coastal habitat }\end{array}$ \\
\hline 7 & $9^{\circ} 11^{\prime} 31.39^{\prime \prime} \mathrm{N}$ & $79^{\circ} 22^{\prime} 36.47^{\prime \prime} \mathrm{E}$ & 3 & $\begin{array}{l}\text { Dhanushkodi: fishing, } \\
\text { tourism site, coastal } \\
\text { habitat }\end{array}$ \\
\hline 8 & $9^{\circ} 10^{\prime} 56.80^{\prime \prime} \mathrm{N}$ & $79^{\circ} 23^{\prime} 28.20^{\prime \prime} \mathrm{E}$ & 3 & $\begin{array}{l}2 \mathrm{~km} \text { from } \\
\text { Dhanushkodi: } \\
\text { fishing, coastal } \\
\text { habitat }\end{array}$ \\
\hline 9 & $9^{\circ} 10^{\prime} 16.82^{\prime \prime} \mathrm{N}$ & $79^{\circ} 24^{\prime} 26.58^{\prime \prime} \mathrm{E}$ & 3 & $\begin{array}{l}4 \text { km from } \\
\text { Dhanushkodi: } \\
\text { fishing, coastal } \\
\text { habitat }\end{array}$ \\
\hline 10 & $9^{\circ} 9^{\prime} 32.87^{\prime \prime} \mathrm{N}$ & $79^{\circ} 25^{\prime} 21.85^{\prime \prime} \mathrm{E}$ & 3 & $\begin{array}{l}6 \text { km from } \\
\text { Dhanushkodi: } \\
\text { fishing, coastal } \\
\text { habitat }\end{array}$ \\
\hline 11 & $9^{\circ} 8^{\prime} 48.74^{\prime \prime} \mathrm{N}$ & $79^{\circ} 26^{\prime} 19.25^{\prime \prime} \mathrm{E}$ & 2 & $\begin{array}{l}\text { South of Arichamunai: } \\
\text { tourism, pilgrimage }\end{array}$ \\
\hline 12 & $9^{\circ} 8^{\prime} 52.05^{\prime \prime} \mathrm{N}$ & $79^{\circ} 27^{\prime} 8.18^{\prime \prime} \mathrm{E}$ & 1 & $\begin{array}{l}\text { Tip: mixing zone } \\
\text { between Palk bay } \\
\text { and Gulf of Mannar }\end{array}$ \\
\hline 13 & $9^{\circ} 8^{\prime} 27.79^{\prime \prime} \mathrm{N}$ & $79^{\circ} 27^{\prime} 33.85^{\prime \prime} \mathrm{E}$ & 1.5 & $\begin{array}{l}\text { Tip1: mixing zone } \\
\text { between Palk bay } \\
\text { and Gulf of Mannar }\end{array}$ \\
\hline
\end{tabular}

prefixed locations (Fig. 1; Table 1) with the help of Global Positioning System (GPS) during spring tide from the average water depths at 4-6 m from April 2011 to March 2012. Samples were collected in separate polythene bottles for nutrients, chlorophyll $a$ and suspended particulate matter (SPM), and in glass stopper bottles for the estimation of DO and BOD, respectively, and stored at $4{ }^{\circ} \mathrm{C}$ for physico-chemical analysis. Water samples were analyzed for various physical, chemical, and biological parameters based on the procedures described in Grasshoff et al. (1983), Srtickland and Parsons (1972). Temperature, pH, 
Fig. 2 Annual precipitation and mean air temperature of Rameswaram Island

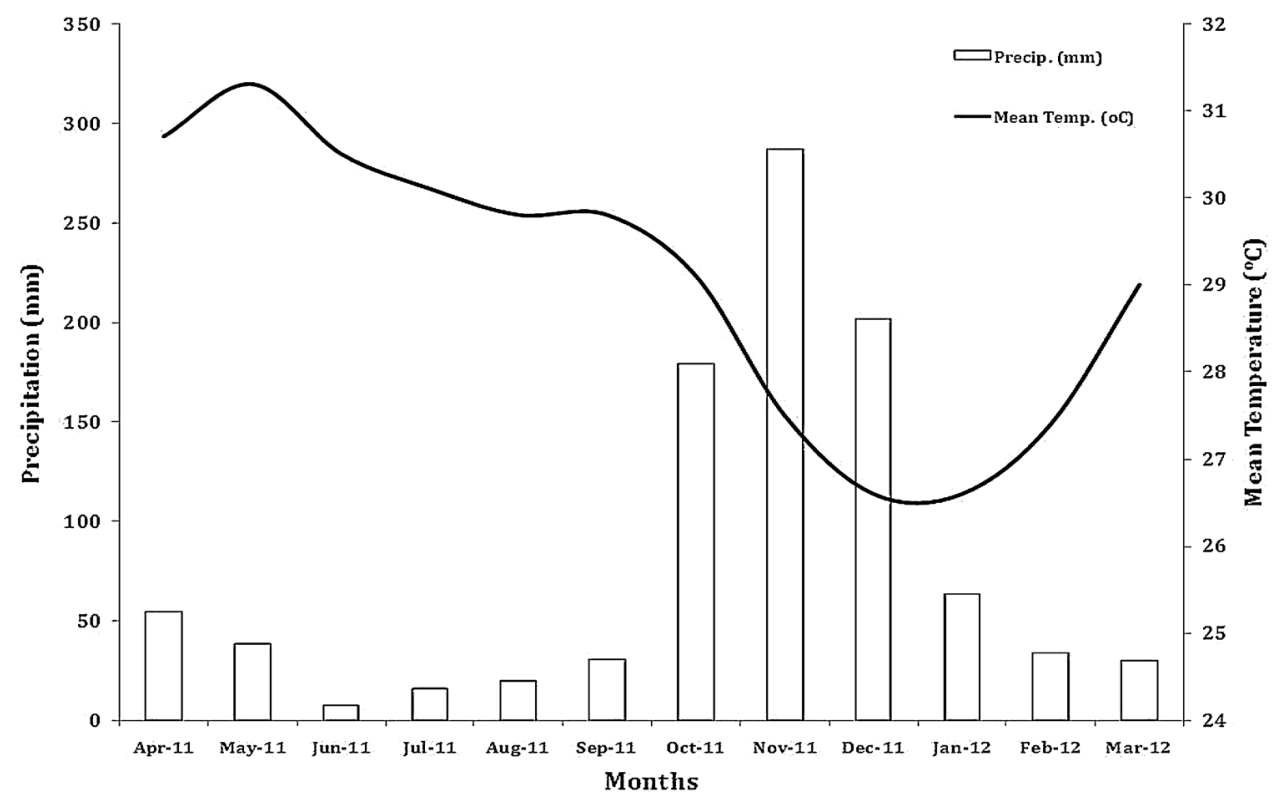

and salinity were measured insitu using digital thermometer, $\mathrm{pH}$ meter (WTW $330 \mathrm{i}$ probe, Germany with 0.01 resolution) and salinity meter (WTW 330i probe with accuracy of \pm 1 digit and $0.1 \mathrm{mS}$ resolution) and turbidity was measured using nephelometer (CyberScan IR TB 100 having 0.01 NTU resolution). DO and BOD concentrations were determined using Winkler's titrimetric methods (Grasshoff et al. 1983). The filtered sample using $0.45 \mu \mathrm{m}$ filter paper for SPM analysis and dissolved nutrients (nitrate, nitrite, ammonia, total nitrogen and total phosphorus) and Chl $a$ is estimated by standard colorimetry methods (Grasshoff et al. 1983). A double beam UV Visible Spectrophotometer (Systronics Visiscan 167) was used for the colorimetry analysis. Correlation coefficients for surface water in the present study were estimated using STATISTICA 8 software. The Spearman rank correlation was used between water quality parameters for the actual values of seasonally analyzed data. From the careful examination of correlation coefficient, the parameters having $r$ values $\geq 0.6$ were considered. Based on the $r$ value, the linkage between the various parameters was developed as follows: significance $(0.8 \leq r \leq 1.0)$; moderate $(0.6 \leq r<0.8)$ and less significant $(0.5 \leq r<0.6)$. CA, PCA and FA were performed on the water quality data for different seasons to discover the structure in the relationships between the water quality parameters, to identify the important parameters which affect the chemistry of surface water in each season and to investigate the possible sources of different pollutants. Prior to the analysis, the data were standardized to produce a normal distribution of all variables, since water quality parameters had different magnitudes and scales of measurements, which if not taken into account would have given more weight to certain variables due to their respective variance. From the standardized covariance or correlation matrix of the data the initial factor solution were extracted by the multivariate principal components extraction, and then a number of $\mathrm{PC}$ were selected from the initial according to their Eigen values.

\section{Results and discussion}

Figure 2 shows the annual climatology variations based on Japan Meteorological Association data (Tokyo Climate Centre, Climate Prediction Division, Japan). The air temperature ranges from 26.9 to $30.9{ }^{\circ} \mathrm{C}$. The peak rainfall $286.8 \mathrm{~mm}$ is recorded during NE monsoon. Anthropogenic influences from pilgrimage activities, tourism, organic contamination from fishing and its processing units and domestic discharges affect the coastal environment considerably. Dilution of pollution load around the Island is mainly dominated by tidal influence. The descriptive statistics of the physico-chemical parameters of Rameswaram Island are shown in Table 2 and the seasonal fluctuation of mean values of water quality parameters are illustrated in box plot (Figs. 3, 4). The box plot is composed of a box around the midpoint (i.e., mean or median) with whiskers outside of the box representing a selected range (i.e., standard error, standard deviation, min-max, or constant). Significant seasonal spatial and temporal variations of all the water quality parameters are revealed. The alkaline $\mathrm{pH}$ was observed during the study period in all stations, where it shows the maximum in SW monsoon because of the high saline water (Manikannan et al. 2011) of GoM in contact with the water from AS. Removal of $\mathrm{CO}_{2}$, photosynthesis 
through bicarbonate degradation, dilution of seawater by freshwater influx, low primary productivity, reduction of salinity and temperature besides decomposition of organic materials are key factors which characterize seasonal fluctuations of $\mathrm{pH}$ (Rajasegar 2003). The analogous trend in $\mathrm{pH}$ in the coastal waters of GoM was reported by Asha and Diwakar (2007) and Bindu et al. (2005). Surface water temperature (Fig. 3) is greatly influenced by the atmospheric temperature. During summer, surface water temperature is higher because of longer photoperiod, clear sunshine and parched wind and is lower in post monsoon, due to obscure sky and heavy rainfall. Similar observations have been recorded by Hannien et al. (2000), Das et al. (1997), Govindasamy et al. (2000), and Damotharan et al. (2010).

Seasonal fluctuation in salinity is significant during the monsoon periods showing high and low values in SW and NE monsoons, respectively. This can be due to the intrusion of high salinity waters from the AS because of the summer monsoon current during July-August (Rao et al. 2011; Mariano et al. 1995), which occurs after the mature phase of the summer monsoon (Jensen 1993) as well as freshwater input due to precipitation during NE monsoon.
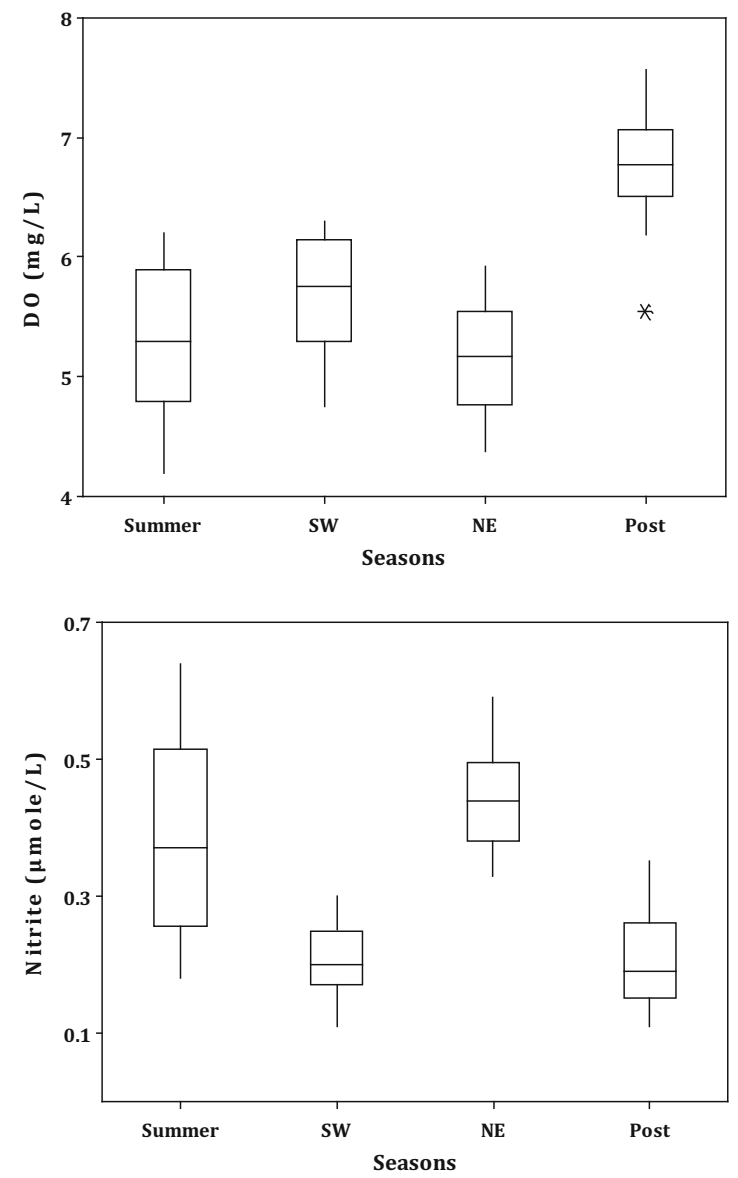

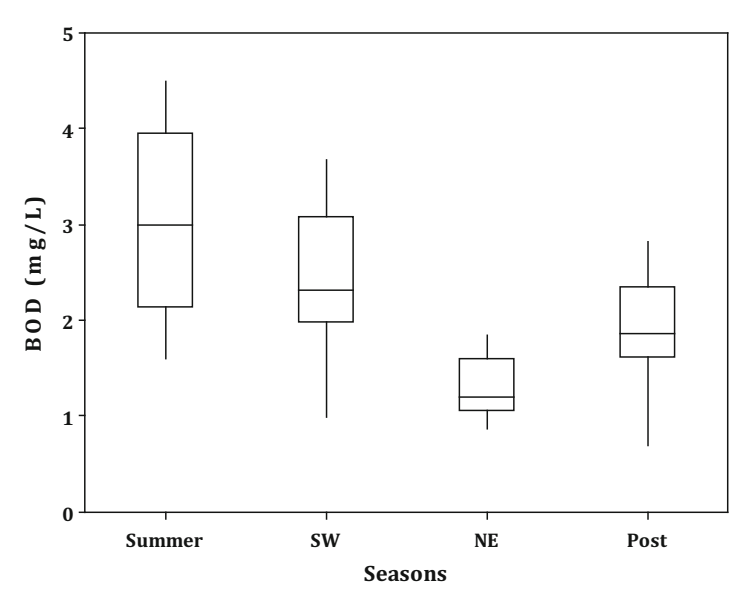

Similar trend in the salinity values is also observed from various parts in southeast coast of India (Seenivasan 1998; Palanichamy and Rajendran 2000; Sulochana and Muniyandi 2005; Prabu et al. 2008; Soundarapandian et al. 2009; Damotharan et al. 2010, Manikannan et al. 2011). During NE monsoon, high concentration of SPM is recorded, because of the turbulence in the buffer zone of the shallow coastal waters experienced by onset of NE monsoon. The maximum and minimum ranges of DO vary between 5.55-7.57 $\mathrm{mg} \mathrm{L}^{-1}$ and 4.37-5.92 $\mathrm{mg} \mathrm{L}^{-1}$ during post monsoon and NE monsoon, respectively. This could be attributed to the solubility of DO saturated with minimum temperature during post monsoon (Das et al. 1997; Prabu et al. 2008; Sundaramanickam et al. 2008; Damotharan et al. 2010, Manikannan et al. 2011) and increased organic inputs from the urban areas during NE monsoon. BOD varies extensively, higher in summer (1.60-4.50) $\mathrm{mg} \mathrm{L}^{-1}$ and low in NE (0.87-1.84) $\mathrm{mg} \mathrm{L}^{-1}$. High BOD recorded at M. K. Chathiram is influenced by fishing, tourism, coastal habitat as well as the discharge of dissolved organic matter from land-based resources (Wu et al. 2009, 2010) (Fig. 3).

Nutrient species of nitrogen (N) such as nitrite-N $\left(\mathrm{NO}_{2}-\mathrm{N}\right)$, nitrate-N $\left(\mathrm{NO}_{3}-\mathrm{N}\right)$, ammonia-N $\left(\mathrm{NH}_{3}-\mathrm{N}\right)$ and

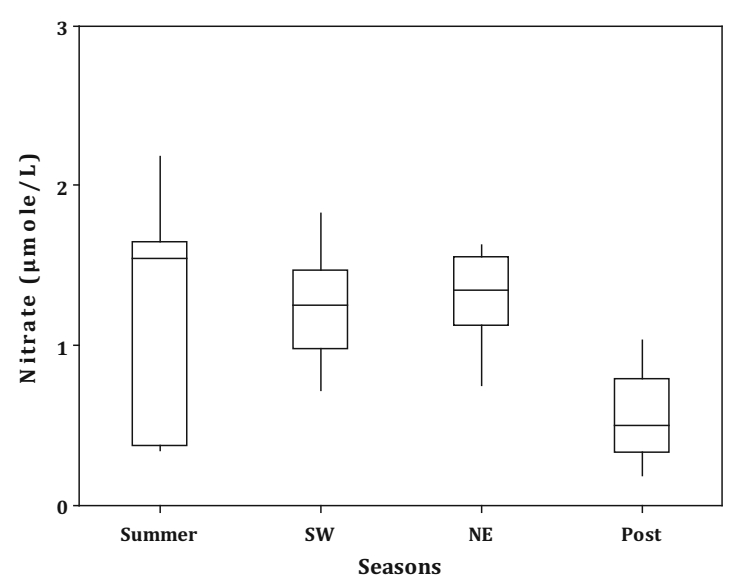

Fig. 3 Seasonal variations of $\mathrm{DO}, \mathrm{BOD}_{3}, \mathrm{NO}_{2}-\mathrm{N}$ and $\mathrm{NO}_{3}-\mathrm{N}$ of Rameswaram Island 
Table 2 Descriptive statistics of seasonal variations of physico-chemical parameters

\begin{tabular}{|c|c|c|c|c|c|c|c|c|c|c|c|c|c|c|}
\hline & $\mathrm{pH}$ & $T$ & $S$ & NTU & SPM & DO & BOD & $\mathrm{NO}_{2}$ & $\mathrm{NO}_{3}$ & $\mathrm{NH}_{4}$ & $\mathrm{TN}$ & $\mathrm{PO}_{4}$ & TP & Chl \\
\hline \multicolumn{15}{|l|}{ Summer } \\
\hline Min. & 8.12 & 29.00 & 29.55 & 1.21 & 31.60 & 4.20 & 1.60 & 0.18 & 0.35 & 1.35 & 12.08 & 0.08 & 1.03 & 1.36 \\
\hline Max. & 8.27 & 31.50 & 30.55 & 3.64 & 68.50 & 6.20 & 4.50 & 0.64 & 2.18 & 6.35 & 25.00 & 0.44 & 2.05 & 3.50 \\
\hline Mean & 8.21 & 30.58 & 30.21 & 1.89 & 48.05 & 5.33 & 3.05 & 0.39 & 1.24 & 3.27 & 18.14 & 0.20 & 1.56 & 1.86 \\
\hline $\mathrm{SD}( \pm)$ & \pm 0.05 & \pm 0.61 & \pm 0.27 & \pm 0.70 & \pm 11.35 & \pm 0.64 & \pm 0.99 & \pm 0.14 & \pm 0.64 & \pm 1.44 & \pm 3.91 & \pm 0.09 & \pm 0.30 & \pm 0.55 \\
\hline \multicolumn{15}{|c|}{ Southwest monsoon } \\
\hline Min. & 8.16 & 28.95 & 31.20 & 3.15 & 50.00 & 4.75 & 1.00 & 0.11 & 0.72 & 0.76 & 21.46 & 0.10 & 1.49 & 0.12 \\
\hline Max. & 8.31 & 30.85 & 32.50 & 6.68 & 76.90 & 6.30 & 3.68 & 0.30 & 1.83 & 4.62 & 27.50 & 0.19 & 3.96 & 1.61 \\
\hline Mean & 8.24 & 29.34 & 31.75 & 4.75 & 60.52 & 5.65 & 2.48 & 0.21 & 1.25 & 1.68 & 24.56 & 0.14 & 2.99 & 1.15 \\
\hline $\mathrm{SD}( \pm)$ & \pm 0.05 & \pm 0.53 & \pm 0.37 & \pm 1.00 & \pm 7.38 & \pm 0.51 & \pm 0.76 & \pm 0.06 & \pm 0.32 & \pm 1.04 & \pm 2.03 & \pm 0.02 & \pm 0.76 & \pm 0.40 \\
\hline \multicolumn{15}{|c|}{ Northeast monsoon } \\
\hline Min. & 8.03 & 27.87 & 28.83 & 2.14 & 58.53 & 4.37 & 0.87 & 0.33 & 0.75 & 3.03 & 34.71 & 0.03 & 0.49 & 0.37 \\
\hline Max. & 8.40 & 31.30 & 31.40 & 6.49 & 102.40 & 5.92 & 1.84 & 0.59 & 1.63 & 7.12 & 48.33 & 0.12 & 2.01 & 1.71 \\
\hline Mean & 8.15 & 28.82 & 29.45 & 3.61 & 68.84 & 5.17 & 1.32 & 0.44 & 1.32 & 5.21 & 39.59 & 0.08 & 1.08 & 1.09 \\
\hline $\mathrm{SD}( \pm)$ & \pm 0.08 & \pm 0.85 & \pm 0.67 & \pm 1.13 & \pm 11.45 & \pm 0.48 & \pm 0.33 & \pm 0.07 & \pm 0.26 & \pm 1.50 & \pm 4.39 & \pm 0.03 & \pm 0.50 & \pm 0.42 \\
\hline \multicolumn{15}{|c|}{ Post monsoon } \\
\hline Min. & 7.87 & 27.87 & 28.09 & 2.80 & 40.67 & 5.55 & 0.69 & 0.11 & 0.19 & 0.54 & 20.00 & 0.16 & 0.33 & 0.41 \\
\hline Max. & 8.02 & 30.60 & 31.46 & 8.19 & 53.33 & 7.57 & 2.83 & 0.35 & 1.03 & 2.65 & 40.00 & 0.36 & 2.05 & 0.93 \\
\hline Mean & 7.96 & 28.61 & 30.04 & 4.55 & 43.94 & 6.77 & 1.93 & 0.20 & 0.56 & 1.80 & 29.21 & 0.26 & 0.98 & 0.68 \\
\hline $\mathrm{SD}( \pm)$ & \pm 0.04 & \pm 0.89 & \pm 1.04 & \pm 1.64 & \pm 3.21 & \pm 0.54 & \pm 0.56 & \pm 0.08 & \pm 0.26 & \pm 0.57 & \pm 7.82 & \pm 0.06 & \pm 0.39 & \pm 0.16 \\
\hline
\end{tabular}

(Units T, Temperature $\left({ }^{\circ} \mathrm{C}\right)$; S, salinity (psu); Turbidity, NTU; SPM, DO and BOD (g/L); $\mathrm{NO}_{2}, \mathrm{NO}_{3}, \mathrm{NH}_{4}, \mathrm{TN}, \mathrm{PO} 4$ and TP ( $\mu$ mol/L); Chl, Chlorophyll $\left.a\left(\mathrm{mg} / \mathrm{m}^{3}\right)\right)$

total nitrogen (TN) show higher values during NE monsoon. During post monsoon except TN other nitrogen species are least, whereas during summer $\mathrm{TN}$ reduced half of its minimum concentration. The maximum values of nitrogen compounds are recorded at M. K. Chathiram. The inorganic phosphorus is high during post monsoon whereas total phosphorus (TP) is high during SW. One of the key factors that enrich the phosphate concentration is the exchange of phosphorous between water and sediment through interstitial water as well as the regenerative property of the sediment is known to play an indispensable role on the distribution of the nutrient (Reddy and Sankaranarayanan 1972; Babu et al. 2000, 2010). The Chl $a$ in the upper layer of tropical oceans is limited by the availability of nutrients. Therefore, oceanic processes that can bring nutrients into the euphotic zone are of prime importance (Kumar et al. 2002; Vinayachandran et al. 2004). High Chlorophyll $a$ values are noticed during summer season and it is low during post monsoon. High water temperature with photoperiod is associated with the occurrence of high chlorophyll concentrations during summer monsoon. The results of unvariate analysis of the environmental data of the coastal water of the GoM region of Rameswaram Island fluctuate seasonally. From Table 3, it is evidenced that the physico chemical parameters of the GoM coastal waters of Rameswaram Island are dynamic, exhibiting a wide range of seasonal variations between SW, NE, post monsoon periods between the 13 stations.

\section{Cluster analysis}

Dendogram of site clustering in relation to sampled physicochemical parameters for all seasons shown in Fig. 5. During summer, based on the different physico chemical characteristics of the sampling stations water quality CA separates four different clusters groups at a 10 distance unit. The cluster groups were represented in the order of four [Dhanushkodi, Tip1, Kodhandaramar kovil, Dhanushkodi $(6 \mathrm{~km})$ ], three [Kunthukal, Mukuntharayar chathiram and Pamban south (7)], four [Dhanushkodi $(2 \mathrm{~km})$, south of Arichamunai, Tip, Dhanushkodi (4 km)] and two (Kurusadai Island and Thavukadu), respectively. During SW monsoon, CA separates four different clusters of the stations groups at 10 distance unit based on the different physicochemical characteristics in this period. The cluster groups were represented in the order of seven [Dhanushkodi $(4 \mathrm{~km})$, Dhanushkodi $(6 \mathrm{~km})$, Dhanushkodi $(2 \mathrm{~km})$, Kunthukal, Kodhandaramar kovil, south of Arichamunai, Tip], five (Mukuntharayar chathiram, Dhanushkodi, Pamban south, Tips, Thavukadu) and one (Kurusadai Island) respectively. During NE monsoon, CA separates two 

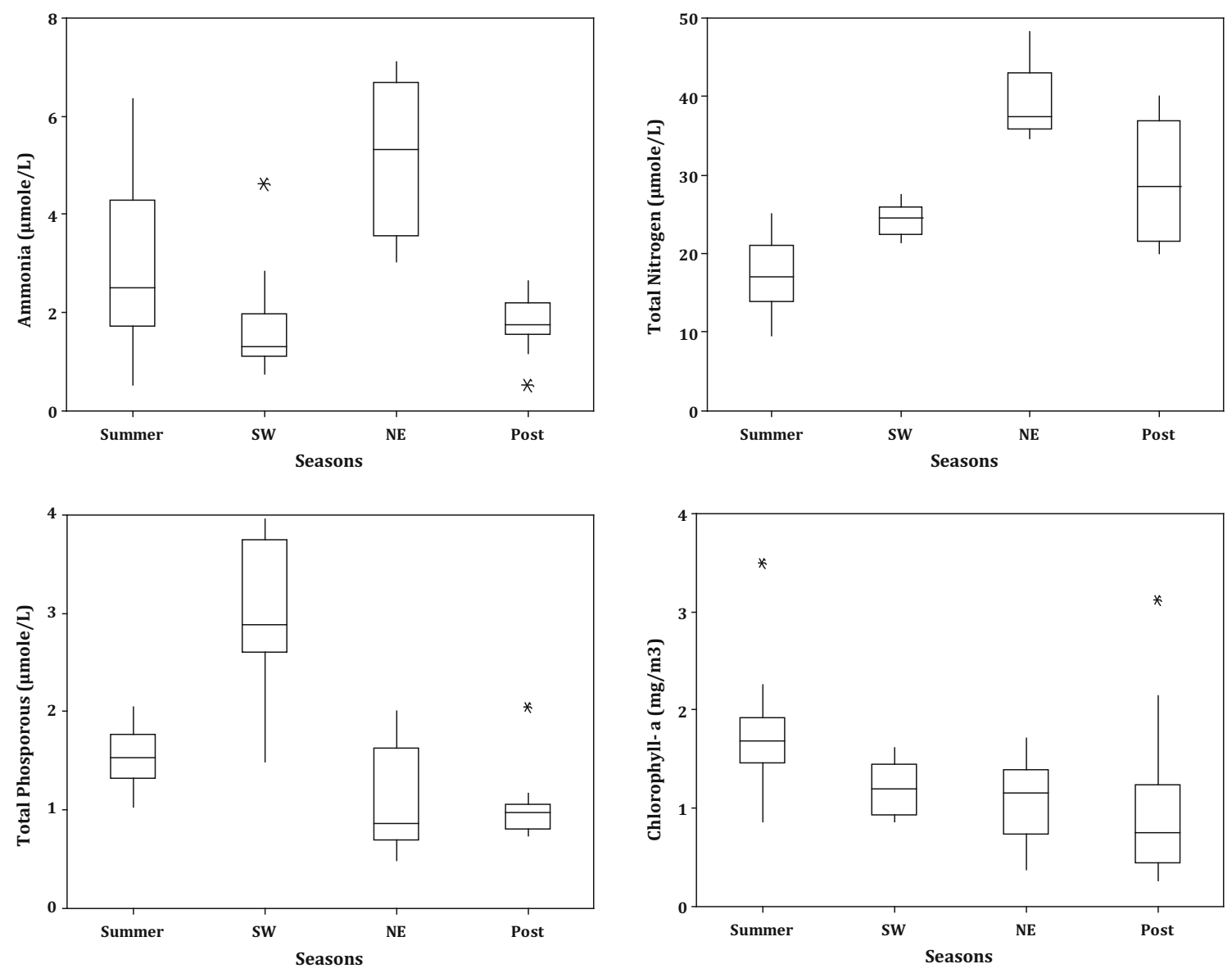

Fig. 4 Seasonal variations of $\mathrm{NH}_{4}-\mathrm{N}, \mathrm{TN}, \mathrm{TP}$ and $\mathrm{Chl} a$ of Rameswaram Island

different clusters of the stations groups at 10 distance unit based on the different physicochemical characteristics in this period. Apart from the tip one site all the locations as formed as the cluster groups. During post monsoon, CA separates four different clusters of the stations groups at 10 distance unit based on the different physicochemical characteristics in this period. The cluster groups were represented in the order of six [Kodhandaramar kovil, Mukuntharayar chathiram, Dhanushkodi, Dhanushkodi (2 km), Kunthukal, Arichamunari south], two (Thavukadu, Tip) and five [Dhanushkodi (4 km), Dhanushkodi $(6 \mathrm{~km})$, Kurusadai Island, Tip1, Pamban south], respectively. The generated dendogram grouped the sampling sites and seasons into three groups. Using this analysis study sites have been categorized into three groups: low pollution (stations $>20$ distance), moderate pollution (stations between 10 and 20 distance) and high pollution (stations $<10$ distance). From these monsoonal variations of grouping of the sampling stations, except NE monsoon all other monsoons formed above two groups. During NE only two groups were formed among 13 stations illustrated that because of the heavy rainfall as well as the influence of the intensity of the NE monsoon homogenized the stations only in two different groups.

\section{Principal component analysis (PCA)}

The water quality trend is inferred by correlation matrix and PCA. The seasonal correlation matrix of 12 variables is given in Table 4. $\mathrm{pH}$ is positively correlated with temperature, salinity and SPM during NE monsoon negatively correlated with inorganic phosphorus, nitrate and ammonia during summer and SW. A negative correlation of temperature with DO in all seasons and with ammonia and nitrite during summer and SW is observed. A positive correlation of salinity with SPM, TP and nitrite is observed in all seasons except SW monsoon and it is negatively correlated with BOD during SW and TN during post monsoon. DO is negatively correlated with BOD in all seasons with inorganic phosphorus during summer. This is because of the dilution of organic load followed by the NE monsoon and oxidation during summer. A negative correlation is observed between nitrite and nitrate with ammonia 


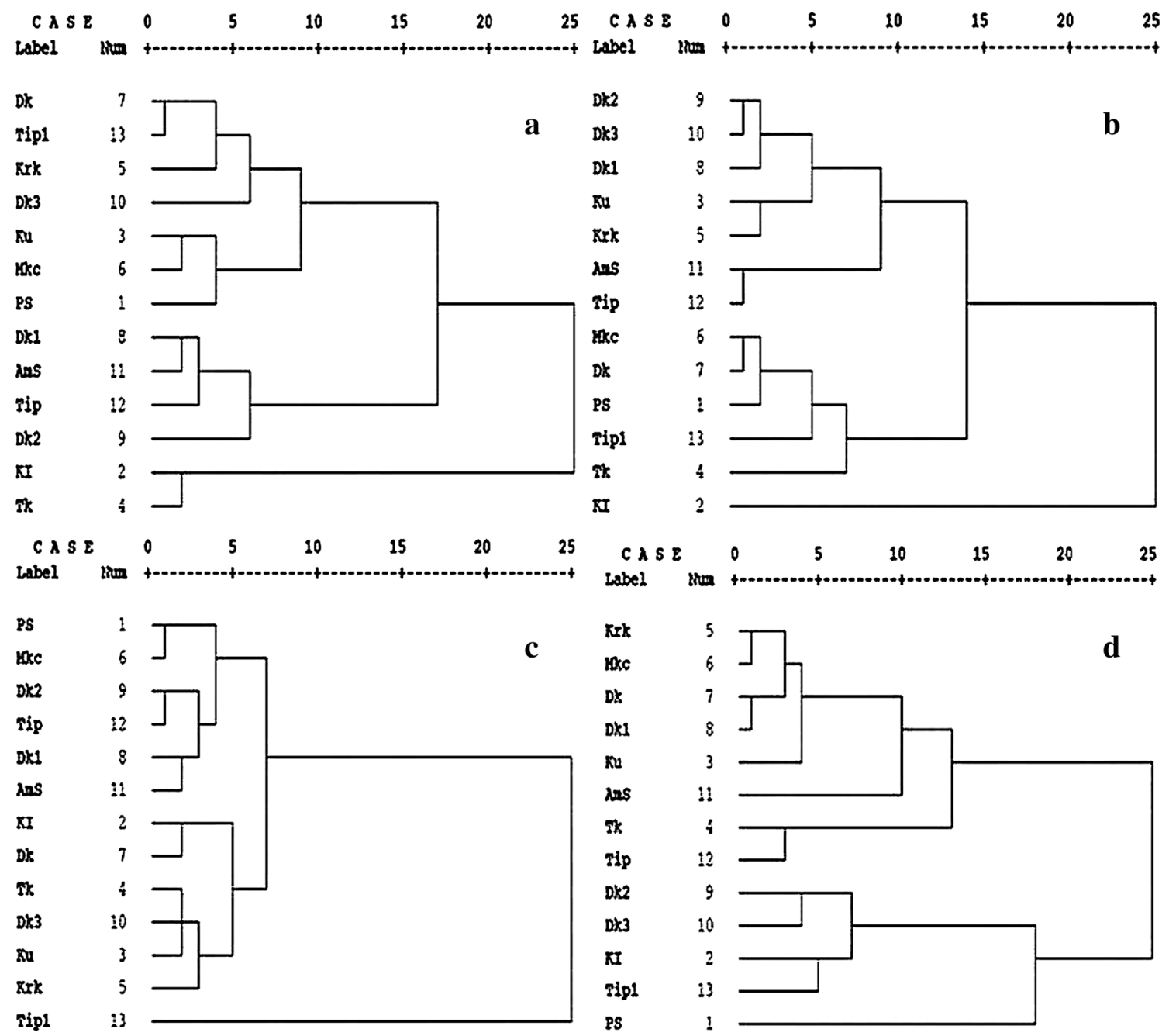

Fig. 5 Dendogram of site clustering in relation to sampled physicochemical parameters in summer (a), southwest monsoon (b) northeast monsoon (c) and post monsoon (d)

during all seasons except summer. A positive correlation of nitrite with nitrate is observed during summer. A positive correlation of TN with chl $a$ is observed during summer. It is found that a strong linear relationship exists between some of the variables from the correlation matrix. Table 5 and Fig. 6 represent the results obtained for the first and second factors in different seasons.

It is observed that factor 1 is dominant in all seasons and together accounted for $37.23 \%$ in summer, $33.97 \%$ in SW, $39.09 \%$ in $\mathrm{NE}$ and $30.71 \%$ in post monsoon of the total variance. During NE monsoon the maximum eigen values of 5.47 are observed due to the nutrients associated with positive loadings of $\mathrm{pH}$, temperature, salinity, SPM, TN and TP $(0.87,0.92,0.85,0.90,0.56$ and $0.69)$. Due to the monsoon impacts, the nutrient enrichment induces the domination factor 1. Factors 2, 3 and 4 are accounted for $16.14,13.05$ and $10.52 \%$ in summer, $18.98,12.440$ and $10.73 \%$ in SW, 19.37, 15.30 and $9.46 \%$ in NE, $24.21,14.41$ and $8.47 \%$ in post monsoon of the total variance. Factors 2, 3 and 4 are dominant during post monsoon, $\mathrm{NE}$ and $\mathrm{SW}$ monsoon, respectively. During post monsoon, factor 2 records an eigen value of 3.39 , because of the nutrients associated with strong positive loading of TP (0.89) and temperature (0.83) as well as strong negative loadings of ammonia $(-0.80)$, respectively. The maximum eigen value of 2.14 for factor 3 during NE monsoon may be attributed to the nutrients associated with strong positive loadings of DO and BOD (0.82 and 0.87), suggesting the dilution of organic loads due to the impact of precipitation. During SW monsoon, factor 4 records an eigen value of 1.50 because of the nutrients associated with strong positive loading of chl $a(0.84)$ and moderate positive loading of inorganic phosphorus (0.68). Factor 2 portrays a strong positive loading with TP during post monsoon and a strong negative loading with TN during summer. This is because of the organic loading which indicates the increased concentration of pollution. In PCA outputs, the positive 

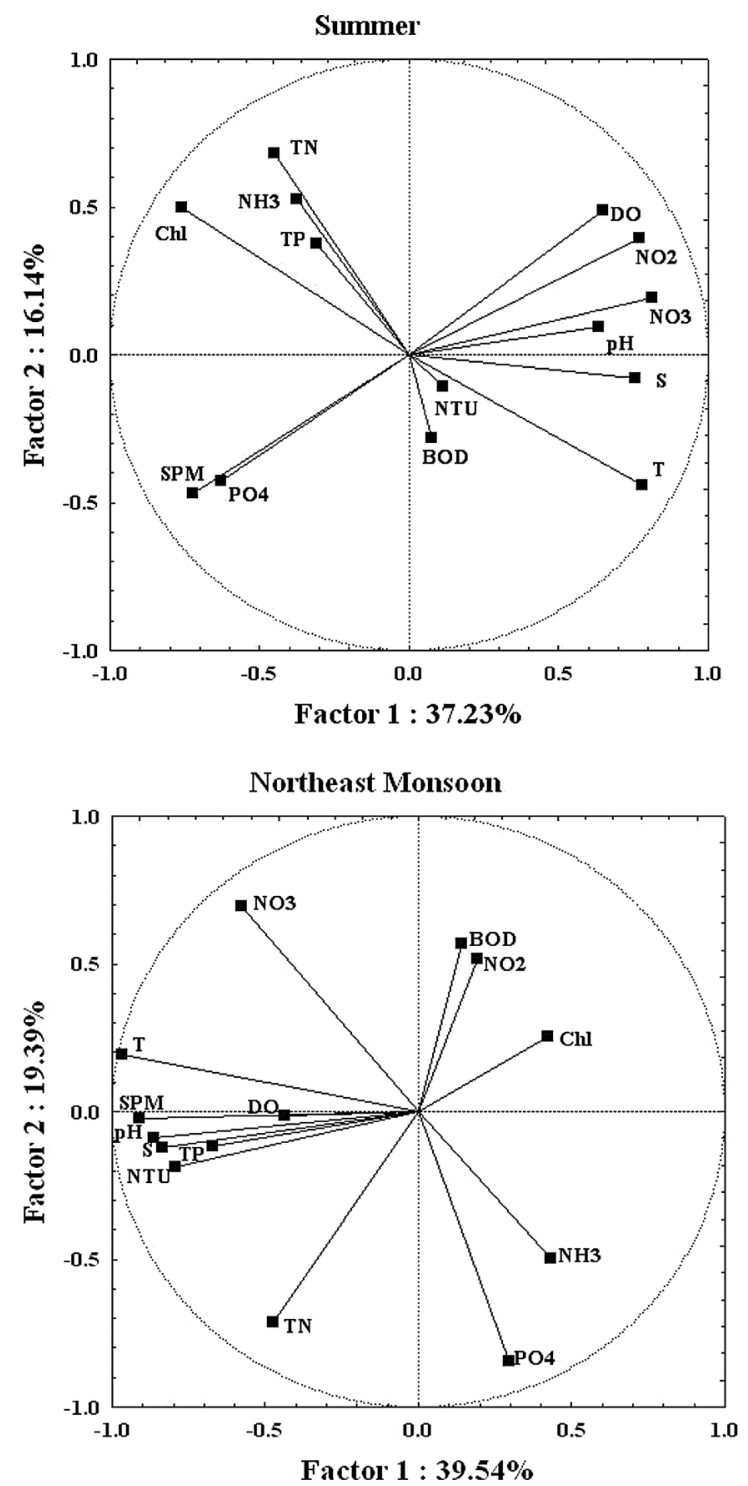

Fig. 6 PCA for seasonal variations of physico-chemical variables

loadings of nutrients along with negative loadings of DO, $\mathrm{pH}$ and temperature indicate that nutrient contribution is related to pollution sources and also it might be due to the consumption of large amounts of oxygen by the organic matter (O'Boyle et al. 1999; Praveena and Aris 2013; Singh et al. 2005; Babu et al. 2010). The major source of ammonia from the sewage which is the indicative of pollution and the presence of nitrate is mainly due to the processes such as nitrification (Radojevic and Bashkin 2006). PCA supported these observations in all seasons.

\section{Conclusion}

The present study concludes that there are spatial and temporal variations in physico chemical variables of the
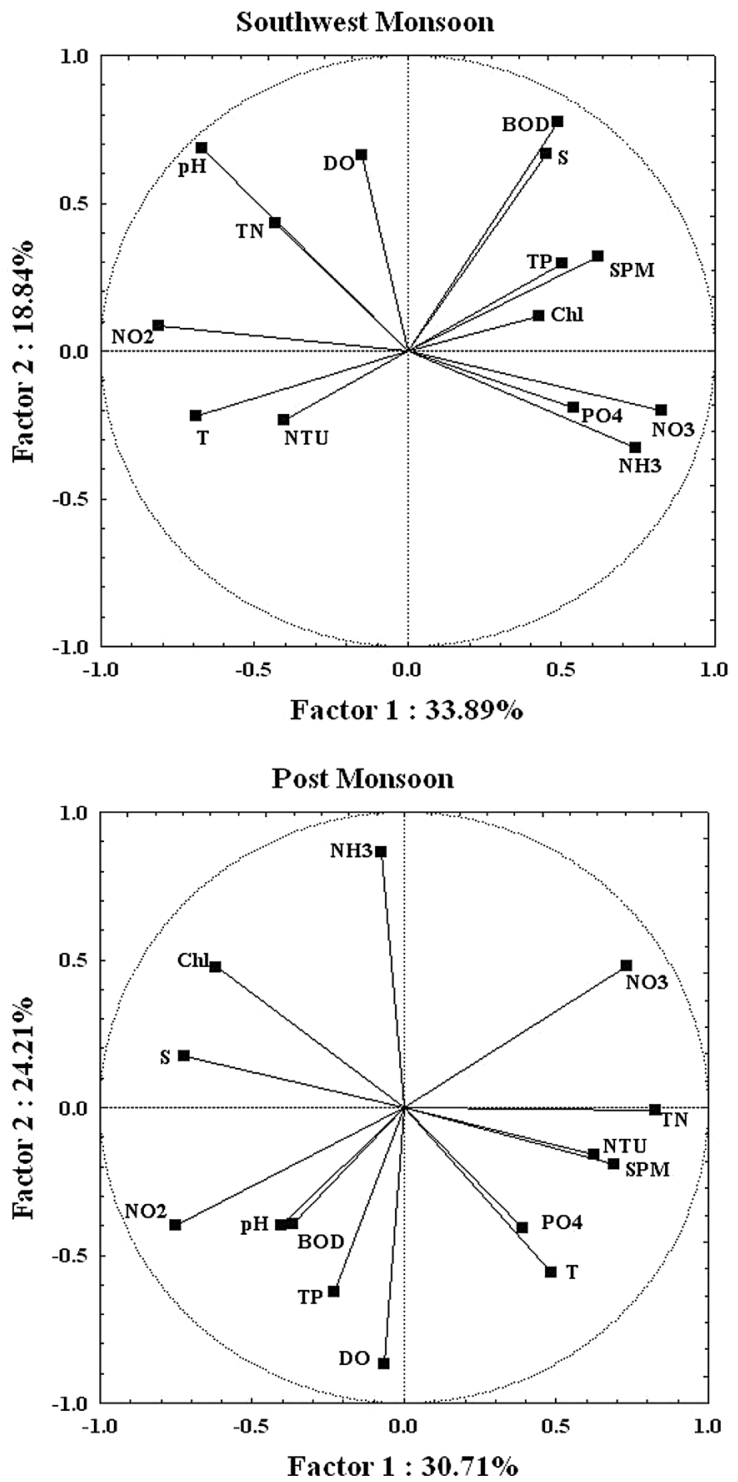

GoM coastal waters especially because of the monsoonal dynamics prevailing in the study area. The maximum enrichment of nutrients during NE monsoon compared with other seasons occurs because of the precipitation. High organic loadings such as, BOD and nitrate is observed during summer in which the temperature recorded is also high. High salinity and DO are observed during SW monsoon in Pamban South and during post monsoon, respectively. The minimum concentration of nutrients, temperature, SPM and salinity are found during post monsoon period and DO is low during summer monsoon around the Rameswaram Island. The multivariate analysis of the physico chemical parameters using CA, PCA and FA assisted in extracting and recognizing factors or sources of origin responsible for water chemistry. PCA/FA identified three latent factors that explained more than $80 \%$ of the 
Table 3 Two-way analysis of variations for physicochemical characteristics of Gulf of Mannar coastal waters of Rameswaram Island among four seasons

\begin{tabular}{lrrrr}
\hline Source of variation & \multicolumn{1}{c}{ SS } & MS & \multicolumn{1}{c}{$P$} & $P$ value \\
\hline $\mathrm{pH}$ & 0.64 & 0.21 & 62.23 & $1.45 \times 10^{-16}$ \\
Temp & 30.40 & 10.13 & 18.75 & $3.46 \times 10^{-08}$ \\
Salinity & 37.40 & 12.47 & 28.49 & $9.93 \times 10^{-11}$ \\
$\mathrm{NTU}$ & 66.24 & 22.08 & 16.21 & $2.07 \times 10^{-07}$ \\
$\mathrm{SPM}$ & $5,096.82$ & $1,698.94$ & 20.94 & $8.14 \times 10^{-09}$ \\
$\mathrm{DO}$ & 20.21 & 6.74 & 22.78 & $2.59 \times 10^{-09}$ \\
$\mathrm{BOD}$ & 21.34 & 7.11 & 14.39 & $8.12 \times 10^{-07}$ \\
$\mathrm{NO}_{2}$ & 0.60 & 0.20 & 22.14 & $3.84 \times 10^{-09}$ \\
$\mathrm{NO}_{3}$ & 4.97 & 1.66 & 10.26 & $2.47 \times 10^{-05}$ \\
$\mathrm{NH}_{4}$ & 104.16 & 34.72 & 21.08 & $7.43 \times 10^{-09}$ \\
$\mathrm{TN}$ & $3,381.91$ & $1,127.30$ & 42.89 & $1.26 \times 10^{-13}$ \\
$\mathrm{TP}$ & 33.42 & 11.14 & 41.54 & 5.01 \\
$\mathrm{Chl} a$ & 5.11 & 1.70 & $5.20 \times 10^{-13}$
\end{tabular}

Two-way analysis of variance for physicochemical characteristics of GoM water quality among the four seasons $(F$ critic $=2.80$ for degrees of freedom 3.00$)$

Table 4 Seasonal correlation coefficient between the physico-chemical parameters

\begin{tabular}{|c|c|c|c|c|c|c|c|c|c|c|c|c|c|c|c|}
\hline & & $\mathrm{pH}$ & $T$ & $S$ & NTU & SPM & DO & BOD & $\mathrm{NO}_{2}$ & $\mathrm{NO}_{3}$ & $\mathrm{NH}_{4}$ & $\mathrm{TN}$ & $\mathrm{PO}_{4}$ & $\mathrm{TP}$ & Chl $a$ \\
\hline \multirow[t]{14}{*}{ Summer } & $\mathrm{pH}$ & 1.00 & & & & & & & & & & & & & \\
\hline & $T$ & 0.60 & 1.00 & & & & & & & & & & & & \\
\hline & $S$ & 0.12 & 0.52 & 1.00 & & & & & & & & & & & \\
\hline & NTU & 0.07 & 0.28 & 0.06 & 1.00 & & & & & & & & & & \\
\hline & SPM & -0.51 & -0.29 & -0.51 & -0.03 & 1.00 & & & & & & & & & \\
\hline & DO & 0.18 & -0.58 & 0.61 & -0.03 & -0.57 & 1.00 & & & & & & & & \\
\hline & BOD & -0.04 & 0.15 & 0.28 & 0.21 & -0.24 & -0.68 & 1.00 & & & & & & & \\
\hline & $\mathrm{NO}_{2}$ & 0.59 & 0.34 & 0.38 & -0.01 & -0.80 & 0.51 & -0.22 & 1.00 & & & & & & \\
\hline & $\mathrm{NO}_{3}$ & 0.29 & 0.46 & 0.73 & 0.27 & -0.78 & 0.61 & 0.28 & 0.74 & 1.00 & & & & & \\
\hline & $\mathrm{NH}_{4}$ & -0.27 & -0.49 & -0.29 & 0.31 & 0.13 & -0.03 & -0.17 & -0.07 & -0.05 & 1.00 & & & & \\
\hline & $\mathrm{TN}$ & -0.18 & -0.55 & -0.32 & 0.06 & -0.03 & -0.04 & 0.09 & -0.19 & -0.14 & 0.52 & 1.00 & & & \\
\hline & $\mathrm{PO}_{4}$ & -0.67 & -0.44 & -0.29 & 0.16 & 0.43 & -0.68 & 0.39 & -0.57 & -0.27 & 0.09 & 0.06 & 1.00 & & \\
\hline & $\mathrm{TP}$ & -0.17 & -0.37 & 0.04 & -0.18 & -0.05 & 0.07 & 0.07 & -0.36 & -0.31 & 0.04 & 0.48 & 0.03 & 1.00 & \\
\hline & Chl $a$ & -0.36 & 0.82 & -0.78 & -0.14 & 0.23 & -0.28 & -0.14 & -0.31 & -0.51 & 0.43 & 0.64 & 0.29 & 0.30 & 1.00 \\
\hline \multirow[t]{14}{*}{ Southwest monsoon } & $\mathrm{pH}$ & 1.00 & & & & & & & & & & & & & \\
\hline & $T$ & 0.24 & 1.00 & & & & & & & & & & & & \\
\hline & $S$ & 0.12 & -0.43 & 1.00 & & & & & & & & & & & \\
\hline & NTU & 0.07 & 0.38 & -0.30 & 1.00 & & & & & & & & & & \\
\hline & SPM & -0.29 & -0.18 & 0.55 & -0.13 & 1.00 & & & & & & & & & \\
\hline & DO & 0.42 & -0.63 & 0.43 & 0.15 & 0.22 & 1.00 & & & & & & & & \\
\hline & BOD & 0.21 & -0.64 & 0.63 & -0.27 & 0.44 & -0.54 & 1.00 & & & & & & & \\
\hline & $\mathrm{NO}_{2}$ & 0.55 & 0.47 & -0.38 & 0.41 & -0.47 & 0.19 & -0.34 & 1.00 & & & & & & \\
\hline & $\mathrm{NO}_{3}$ & -0.68 & -0.55 & 0.22 & -0.18 & 0.55 & -0.27 & 0.20 & -0.54 & 1.00 & & & & & \\
\hline & $\mathrm{NH}_{4}$ & -0.75 & -0.52 & 0.08 & -0.14 & 0.09 & -0.14 & 0.23 & -0.60 & 0.59 & 1.00 & & & & \\
\hline & $\mathrm{TN}$ & 0.65 & 0.20 & -0.19 & -0.27 & -0.33 & 0.22 & 0.08 & 0.55 & -0.31 & -0.40 & 1.00 & & & \\
\hline & $\mathrm{PO}_{4}$ & -0.54 & -0.12 & -0.10 & -0.38 & 0.22 & -0.09 & -0.03 & -0.31 & 0.56 & 0.49 & 0.11 & 1.00 & & \\
\hline & $\mathrm{TP}$ & -0.05 & -0.46 & 0.15 & -0.30 & 0.31 & -0.20 & 0.53 & -0.24 & 0.30 & 0.18 & 0.12 & 0.42 & 1.00 & \\
\hline & Chl $a$ & -0.21 & 0.02 & 0.20 & 0.07 & 0.53 & 0.06 & 0.19 & -0.24 & 0.41 & 0.29 & 0.04 & 0.33 & 0.31 & 1.00 \\
\hline
\end{tabular}


Table 4 continued

\begin{tabular}{|c|c|c|c|c|c|c|c|c|c|c|c|c|c|c|c|}
\hline & & $\mathrm{pH}$ & $T$ & $S$ & NTU & SPM & DO & BOD & $\mathrm{NO}_{2}$ & $\mathrm{NO}_{3}$ & $\mathrm{NH}_{4}$ & $\mathrm{TN}$ & $\mathrm{PO}_{4}$ & TP & Chl $a$ \\
\hline \multirow[t]{14}{*}{ Northeast monsoon } & $\mathrm{pH}$ & 1.00 & & & & & & & & & & & & & \\
\hline & $T$ & 0.77 & 1.00 & & & & & & & & & & & & \\
\hline & $S$ & 0.77 & 0.78 & 1.00 & & & & & & & & & & & \\
\hline & NTU & 0.70 & 0.68 & 0.59 & 1.00 & & & & & & & & & & \\
\hline & SPM & 0.69 & 0.91 & 0.72 & 0.63 & 1.00 & & & & & & & & & \\
\hline & DO & 0.30 & -0.42 & 0.72 & 0.32 & 0.37 & 1.00 & & & & & & & & \\
\hline & BOD & -0.16 & -0.02 & 0.16 & -0.23 & -0.20 & 0.49 & 1.00 & & & & & & & \\
\hline & $\mathrm{NO}_{2}$ & -0.25 & -0.03 & -0.33 & -0.10 & -0.28 & -0.06 & 0.50 & 1.00 & & & & & & \\
\hline & $\mathrm{NO}_{3}$ & 0.35 & 0.69 & 0.31 & 0.33 & 0.50 & 0.23 & 0.12 & 0.17 & 1.00 & & & & & \\
\hline & $\mathrm{NH}_{4}$ & -0.42 & -0.48 & -0.07 & -0.30 & -0.39 & 0.34 & 0.27 & 0.07 & -0.68 & 1.00 & & & & \\
\hline & $\mathrm{TN}$ & 0.47 & 0.35 & 0.49 & 0.51 & 0.43 & 0.32 & -0.25 & -0.14 & -0.30 & 0.39 & 1.00 & & & \\
\hline & $\mathrm{PO}_{4}$ & -0.05 & -0.29 & 0.01 & 0.11 & -0.20 & 0.05 & -0.50 & -0.38 & -0.55 & 0.38 & 0.42 & 1.00 & & \\
\hline & $\mathrm{TP}$ & 0.49 & 0.63 & 0.48 & 0.62 & 0.48 & 0.00 & -0.36 & -0.17 & 0.40 & -0.37 & 0.34 & 0.05 & 1.00 & \\
\hline & Chl $a$ & -0.31 & -0.43 & -0.20 & -0.26 & -0.54 & -0.04 & 0.29 & -0.17 & -0.02 & 0.01 & -0.50 & -0.09 & -0.12 & 1.00 \\
\hline \multirow[t]{14}{*}{ Post monsoon } & $\mathrm{pH}$ & 1.00 & & & & & & & & & & & & & \\
\hline & $T$ & -0.14 & 1.00 & & & & & & & & & & & & \\
\hline & $S$ & 0.03 & -0.21 & 1.00 & & & & & & & & & & & \\
\hline & NTU & 0.34 & 0.25 & -0.36 & 1.00 & & & & & & & & & & \\
\hline & SPM & 0.06 & 0.18 & -0.70 & 0.58 & 1.00 & & & & & & & & & \\
\hline & DO & 0.07 & -0.22 & -0.69 & 0.27 & 0.72 & 1.00 & & & & & & & & \\
\hline & BOD & 0.38 & 0.24 & -0.19 & -0.05 & 0.13 & -0.53 & 1.00 & & & & & & & \\
\hline & $\mathrm{NO}_{2}$ & 0.11 & -0.03 & 0.18 & -0.31 & -0.02 & 0.03 & 0.51 & 1.00 & & & & & & \\
\hline & $\mathrm{NO}_{3}$ & 0.61 & -0.21 & 0.27 & -0.09 & -0.37 & -0.44 & 0.37 & 0.40 & 1.00 & & & & & \\
\hline & $\mathrm{NH}_{4}$ & -0.54 & 0.20 & -0.26 & -0.04 & 0.22 & 0.44 & -0.50 & -0.40 & -0.76 & 1.00 & & & & \\
\hline & $\mathrm{TN}$ & -0.10 & -0.64 & -0.02 & -0.36 & -0.14 & -0.09 & -0.65 & -0.22 & -0.11 & 0.30 & 1.00 & & & \\
\hline & $\mathrm{PO}_{4}$ & -0.26 & 0.61 & -0.43 & 0.08 & 0.26 & 0.46 & -0.14 & -0.31 & -0.53 & 0.75 & -0.02 & 1.00 & & \\
\hline & $\mathrm{TP}$ & -0.06 & 0.40 & -0.36 & -0.03 & -0.01 & 0.08 & 0.48 & -0.10 & -0.08 & 0.04 & -0.41 & 0.48 & 1.00 & \\
\hline & Chl $a$ & 0.27 & 0.56 & 0.30 & 0.23 & -0.30 & -0.11 & 0.33 & 0.11 & 0.35 & -0.22 & $-\mathbf{0 . 7 0}$ & -0.02 & 0.08 & 1.00 \\
\hline
\end{tabular}

Table 5 Factor analysis

\begin{tabular}{|c|c|c|c|c|c|c|c|c|}
\hline & Factor 1 & Factor 2 & Factor 3 & Factor 4 & Factor 1 & Factor 2 & Factor 3 & Factor 4 \\
\hline Summer & & & & & \multicolumn{4}{|c|}{ Southwest monsoon } \\
\hline $\mathrm{pH}$ & 0.04 & 0.24 & 0.01 & 0.04 & -0.87 & 0.30 & 0.02 & -0.31 \\
\hline Temp & 0.23 & 0.75 & 0.13 & 0.20 & -0.48 & -0.32 & -0.67 & 0.18 \\
\hline Salinity & 0.83 & 0.46 & 0.23 & -0.08 & 0.16 & 0.86 & 0.18 & 0.00 \\
\hline NTU & 0.07 & -0.05 & 0.29 & 0.77 & -0.05 & -0.02 & -0.78 & 0.01 \\
\hline SPM & -0.68 & 0.08 & -0.25 & 0.01 & 0.33 & 0.61 & -0.02 & 0.55 \\
\hline DO & 0.86 & 0.02 & -0.28 & -0.13 & -0.39 & 0.66 & -0.21 & 0.11 \\
\hline BOD & 0.07 & 0.06 & 0.93 & 0.07 & 0.02 & 0.77 & 0.52 & 0.04 \\
\hline $\mathrm{NO}_{2}$ & 0.56 & 0.08 & -0.24 & 0.22 & -0.75 & -0.26 & -0.29 & -0.11 \\
\hline $\mathrm{NO}_{3}$ & 0.82 & 0.16 & 0.20 & 0.36 & 0.67 & 0.06 & 0.28 & 0.48 \\
\hline $\mathrm{NH}_{3}$ & 0.07 & -0.70 & -0.22 & 0.47 & 0.73 & -0.05 & 0.27 & 0.22 \\
\hline $\mathrm{TN}$ & 0.00 & -0.88 & 0.19 & -0.08 & -0.85 & -0.14 & 0.37 & 0.17 \\
\hline $\mathrm{PO}_{4}$ & -0.42 & -0.10 & 0.45 & 0.20 & 0.23 & -0.31 & 0.42 & 0.68 \\
\hline $\mathrm{TP}$ & 0.09 & -0.44 & 0.28 & -0.67 & 0.02 & 0.12 & 0.68 & 0.37 \\
\hline
\end{tabular}


Table 5 continued

\begin{tabular}{|c|c|c|c|c|c|c|c|c|}
\hline & Factor 1 & Factor 2 & Factor 3 & Factor 4 & Factor 1 & Factor 2 & Factor 3 & Factor 4 \\
\hline Chl & -0.41 & -0.82 & -0.10 & -0.12 & 0.09 & 0.22 & -0.05 & 0.84 \\
\hline Eigen value & 5.21 & 2.26 & 1.83 & 1.47 & 4.76 & 2.66 & 1.74 & 1.50 \\
\hline$\%$ Total & 37.23 & 16.14 & 13.05 & 10.52 & 33.97 & 18.98 & 12.44 & 10.73 \\
\hline Cumulative & 37.23 & 53.37 & 66.42 & 76.94 & 33.97 & 52.95 & 65.39 & 76.12 \\
\hline \multicolumn{5}{|c|}{ Northeast monsoon } & \multicolumn{4}{|c|}{ Post monsoon } \\
\hline $\mathrm{pH}$ & 0.87 & 0.04 & 0.00 & -0.04 & 0.07 & 0.10 & 0.14 & 0.12 \\
\hline Temp & 0.92 & 0.30 & 0.10 & 0.17 & 0.12 & 0.83 & 0.17 & -0.29 \\
\hline Salinity & 0.85 & -0.09 & 0.44 & -0.18 & -0.14 & 0.15 & -0.78 & 0.44 \\
\hline NTU & 0.82 & -0.06 & -0.05 & 0.02 & -0.08 & -0.04 & 0.92 & -0.03 \\
\hline SPM & 0.90 & 0.11 & -0.01 & 0.14 & 0.05 & 0.12 & 0.92 & 0.00 \\
\hline DO & 0.43 & -0.16 & 0.82 & -0.10 & -0.57 & 0.34 & 0.23 & -0.43 \\
\hline BOD & -0.24 & 0.31 & 0.87 & 0.13 & -0.84 & 0.10 & 0.02 & 0.13 \\
\hline $\mathrm{NO}_{2}$ & -0.29 & 0.32 & 0.23 & 0.75 & -0.33 & 0.04 & -0.34 & 0.04 \\
\hline $\mathrm{NO}_{3}$ & 0.48 & 0.78 & 0.06 & 0.02 & 0.55 & 0.03 & 0.31 & 0.09 \\
\hline $\mathrm{NH}_{3}$ & -0.37 & -0.72 & 0.48 & 0.12 & 0.37 & -0.80 & -0.07 & 0.31 \\
\hline $\mathrm{TN}$ & 0.56 & -0.71 & 0.07 & 0.26 & 0.55 & 0.31 & 0.36 & -0.35 \\
\hline $\mathrm{PO}_{4}$ & 0.00 & -0.81 & -0.24 & -0.24 & 0.16 & 0.15 & -0.05 & -0.90 \\
\hline $\mathrm{TP}$ & 0.69 & 0.09 & -0.30 & -0.12 & -0.02 & 0.89 & -0.23 & 0.10 \\
\hline Chl & -0.43 & 0.26 & 0.21 & -0.74 & 0.08 & -0.19 & -0.41 & 0.71 \\
\hline Eigen value & 5.47 & 2.71 & 2.14 & 1.32 & 4.30 & 3.39 & 2.02 & 1.19 \\
\hline$\%$ Total & 39.09 & 19.37 & 15.30 & 9.46 & 30.71 & 24.21 & 14.41 & 8.47 \\
\hline Cumulative & 39.09 & 58.46 & 73.77 & 83.23 & 30.71 & 54.91 & 69.32 & 77.79 \\
\hline
\end{tabular}

total variance of 12 parameters. The major anthropogenic impacts on the coastal waters of the study area are due to the intensification of tourism, fishing and urbanization by discharging sewage from hotels and settlements directly into the sea. These discharges lead to degradation of coastal water quality causing significant negative impacts on marine ecosystem in water quality, aquatic organisms and coral reefs in particular (Chua et al. 1997; Mokhtar et al. 2009; Praveena and Aris 2013). This study reveals the usefulness of multivariate statistical techniques for analysis and interpretation of complex data sets, and also for identification of pollution sources and better understanding of seasonal variations in water quality for effective coastal water quality management.

Acknowledgments Authors are thankful to the Ministry of Earth Sciences (MoES), Government of India, for financial assistance; Principal Chief Conservator of Forests and Chief Wildlife Warden, Tamil Nadu Forest Department and Wildlife Warden, Gulf of Mannar Marine National Park for research permission.

Open Access This article is distributed under the terms of the Creative Commons Attribution License which permits any use, distribution, and reproduction in any medium, provided the original author(s) and the source are credited.

\section{References}

Asha PS, Diwakar K (2007) Hydrobiology of the inshore waters off Tuticorin in the Gulf of Mannar. J mar Biol Ass India 49(1):7-11

Babu KN, Ouseph P, Padmalal D (2000) Interstitial water-sediment geochemistry of $\mathrm{N}, \mathrm{P}$ and $\mathrm{Fe}$ and its response to overlying waters of tropical estuaries: a case from the south west coast of India. Environ Geol 39(6):633-640

Babu KN, Omana PK, Mohan M (2010) Water and Sediment quality of Ashtamudi estuary, a Ramsar site, southwest coast of India-a statistical appraisal. Environ Monit Assess 165:307-319

Brandini FP, Silva AS, Silva ET, Kolm H (2007) Sources of nutrients and seasonal dynamics of chlorophyll in the inner shelf of Paraná State-South Brazil Bight. J Coast Res 23:1131-1140

Bu H, Tan X, Li S, Zhang Q (2009) Water quality assessment of the Jinshui River (China) using multivariate statistical techniques. Environ Earth Sci 60(8):1631-1639

Chua TE, Ross SA, Yu H (1997) Malacca Straits Environmental Profile. In: Aquatic resource and environmental studies of the Straits of Malacca: managing the straits through science and technology. Serdang, Malaysia

Damotharan P, Vengadesh Perumal N, Arumugam M, Vijayalakshmi S, Balasubramanian T (2010) Seasonal variation of physicochemical characteristics in Point Calimere coastal waters (South East Coast of India). Middle East J Sci Res 6(4):333-339

Das J, Sad SN, Sahoo RK (1997) Semidiurnal variation of some physic-chemical parameters in the Mahanadhi estuary, East coast of India. Indian J Mar Sci 26:323-326 
Fathy SAH, Hamid FFA, Shreadah MA, Mohamed LA, El-Gazar MG (2012) Application of principal component analysis for developing water quality index for selected coastal areas of Alexandria Egypt. Resour Environ 2(6):297-305

Fock HO (2003) Changes in the seasonal cycles of inorganic nutrients in the coastal zone of the southeastern North Sea from 1960 to 1997: effects of eutrophication and sensitivity to meteoclimatic factors. Marine Pollut Bull 46:1434-1449

Gonzalez-Rodriguez E, Valentin JL, André DL, Jacob AS (1992) Upwelling and down welling at Cabo Frio (Brazil): comparison of biomass and primary productivity response. J Plankton Res 14(2):289-306

Govindasamy C, Kannan L, Jayapal Azariah (2000) Seasonal variation in physic-chemical properties and primary production in the coastal water biotopes of Coromandel Coast. India $\mathbf{J}$ Environ Biol 21(1):1-7

Grasshoff K, Ehrhordt M, Kremling K (1983) Methods of seawater analysis. Chemie, Weinheim

Hannien J, Vuorinen T, Helminen H, Kirkkala T, Lehtila K (2000) Trends and gradients in nutrient concentrations and loading in the archipielago sea, North Baltic, in 1997. East Coast Shelf Sci 50:153-171

Jensen TG (1993) Equatorial variability and resonance in a winddriven Indian Ocean model. J Geophys Res 98(22):533-552

Jyothibabu R, Mohan Arya P, Jagadeesan L, Anjusha A, Muraleedharan KR, Lallu KR, Krishna Kiran Ullas N (2013) Ecology and trophic preference of picoplankton and nanoplankton in the Gulf of Mannar and the Palk Bay, southeast coast of India. J Mar Syst 111-112:29-44

Kumar SP, Muraleedharan PM, Prasad TG, Gauns M, Ramaiah N, de Souza SN, Sardesai S, Madhupratap M (2002) Why is the Bay of Bengal less productive during summer monsoon compared to the Arabian Sea? Geophys Res Lett 29(24):88.1-88.4

Liu CW, Lin KH, Kuo YM (2003) Application of factor analysis in the assessment of ground water quality in a Blackfoot disease area in Taiwan. Sci Total Environ 313(1-3):77-89

Manikannan R, Asokan S, Samsoor AHM (2011) Seasonal variations of physico-chemical properties of the Great Vedaranyam Swamp, Point Calimare Wildlife Sanctuary, South-East coast of India. Afr J Environ Sci Technol 5(9):673-681

Mariano AJ, Ryan EH, Perkins BD, Smithers S (1995) The Mariano Global Surface Velocity Analysis 1.0: USCG Report CG-D 34-95. Office of Engineering, Logistics and Development, U.S. Coast Guard

Matsuura Y (1986) Contribuição ao estudo da estrutura oceanográfica da região sudeste entre Cabo Frio (RJ) e Cabo Santa Marta Grande (SC). Ciência e Cultura 38(8):1439-1450

Mazlum N, Ozer A, Mazlum S (1993) Interpretation of water quality data by principal components analysis. Turk J Eng Environ Sci 23:19-26

Mokhtar MB, Aris AZ, Munusamy V, Praveena SM (2009) Assessment level of heavy metals in Penaeus Monodon and Oreochromis Spp in selected aquaculture ponds of high densities development area. Eur J Sci Res 30:348-360

Murty AVS, Varma PU (1964) The hydrographical features of Palk Bay during March 1963. Mar Biol Assoc India 6:207-216

O’Boyle S, McDermott G, Wilkes R (1999) Dissolved oxygen levels in estuarine and coastal waters around Ireland. Mar Pollut Bull 58:1657-1663

Palanichamy S, Rajendran A (2000) Heavy metal concentration in seawater and sediments of Gulf of Mannar and Palk Bay, southeast coast of India. Indian J Mar Sci 29:116-119

Panda UC, Sundaray SK, Rath P, Nayak BB, Bhatta D (2006) Application of factor and cluster analysis for characterization of river and estuarine water systems - a case study: Mahanadi River (India). J Hydrol 331(3-4):434-445
Prabu VA, Rajkumar M, Perumal P (2008) Seasonal variations in physico-chemical characteristics of Pichavaram mangroves, southeast coast of India. J Environ Biol 29(6):945-950

Praveena SM, Aris AZ (2013) A baseline study of tropical coastal water quality in Port Dickson, Strait of Malacca. Malays Mar Pollut Bull 67:196-199

Radojevic M, Bashkin VN (2006) Practical environmental analysis. Royal Society of Chemistry, Cambridge

Rajasegar M (2003) Physico-chemical characteristics of the Vellar estuary in relation to shrimp farming. J Environ Biol 24(1):95-101

Rao SA, Saha SK, Pokhel S, Sundar D, Dhakate AR, Mahapatra S, Ali S, Chaudhari HS, Shreeam P, Vasimalla S, Srikanth AS, Suresh RRV (2011) Modulation of SST, SSS over northern Bay of Bengal on ISO time scale. J Geophys Res 116

Reddy CVG, Sankaranarayanan VN (1972) Phosphate regenerative activity in the muds of tropical estuary. Indian J Mar Sci 1:57-60

Reghunath R, Murthy TRS, Raghavan BR (2002) The utility of multivariate statistical techniques in hydrogeochemical studies: an example from Karnataka, India. Water Res 36(10):2437-2442

Seenivasan R (1998) Spectral reflectance properties of the Vellar estuarine environment, southeast coast of India. M.Phil. Thesis, Annamalai University, India

Shrestha S, Kazama F (2007) Assessment of surface water quality using multivariate statistical techniques: a case study of the Fuji river basin. Jpn Environ Model Softw 22(4):464-475

Simonassi JC, Hennemann MC, Talgatti D, Marques AN (2010) Nutrient variations and coastal water quality of Santa Catarina Island, Brazil. Biotemas 23(1):211-223

Singh KP, Malik A, Sinha S (2005) Water quality assessment and appropriation of pollution sources of Gomti River (India) using multivariate statistical techniques-a case study. Anal Chim Acta 538:355-374

Soundarapandian P, Premkumar T, Dinakaran GK (2009) Studies on the physico- chemical characteristic and nutrients in the Uppanar estuary of Cuddalore, South east coast of India. Curr Res J Biol Sci 1(3): 102-105

Srtickland JDH, Parsons TR (1972) A practical hand book of seawater analysis. Bull Fish Res Bd Can 167:310

Sulochana B, Muniyandi K (2005) Hydrographic parameters off Gulf of Mannar and Palk Bay during an year of abnormal rainfall. J Mar Biol Assoc India 47(2):198-200

Sundaramanickam A, Sivakumar T, Kumaran R, Ammaiappan V, Velappan RA (2008) comparative study of physico-chemical investigation along Parangipettai and Cuddalore coast. J Environ Sci Technol 1(1):1-10

Tokyo Climate Centre, Climate Prediction Division, 1-3-4 Otemachi, Chiyoda-ku, Tokyo, Japan.http://ds.data.jma.go.jp/gmd/tcc/ climatview/obsmonth.jsp? $\mathrm{n}=43363 \& \mathrm{dt}=2013-06-02 \& \mathrm{t}=60$ \& prt=1

Valentin JL (1994) A ressurgência - Fonte de vida dos oceanos. Ciência e Cultura 18:178-183

Vinayachandran PN, Chauhan P, Mohan M, Nayak S (2004) Biological response of the sea around Sri Lanka to summer monsoon. Geophys Res Lett 31(1):1-4

Wu ML, Wang YS, Sun CC, Wang H, Dong JD, Yin JP, Han SH (2010) Identification of coastal water quality by statistical analysis methods in Daya Bay. South China Sea Mar Pollut Bull 60(6):852-860

Wu ML, Wang YS, Sun CC, Wang H, Dong JD (2009) Using chemometrics toidentify water quality in Daya Bay. China Oceanol 52:217-232

Yu S, Shang J, Zhao J, Guo H (2003) Factor analysis and dynamics of water quality of the Songhua River Northeast China. Water Air Soil Pollut 144(1-4):159-169

Zare Garizi A, Sheikh V, Sadoddin A (2011) Assessment of chemical characteristics in surface water using multivariate statistical methods. Int J Environ Sci Tech 8(3):581 